PREVENTIVE HEALTHCARE:

TOPICAL ISSUES OF HEALTH RISK ANALYSIS

UDC $001.89 ; 613$

DOI: $10.21668 /$ health.risk/2021.2.01.eng

Read

online

Research article

\title{
SANITARY-EPIDEMIOLOGICAL SURVEILLANCE: A NEW STAGE IN DEVELOPMENT STIMULATED BY DIGITALIZATION AND CHANGES IN LEGISLATION
}

\section{N.V. Zaitseva, I.V. May, D.A. Kiryanov, S.V. Babina, M.R. Kamaltdinov}

Federal Scientific Center for Medical and Preventive Health Risk Management Technologies, 82 Monastyrskaya Str., Perm, 614045, Russian Federation

The paper dwells on methodical approaches that provide implementation of provisions fixed by the Federal Law No. 248 «On state control (surveillance) and municipal control on the Russian Federation» that comes into force on July 01, 2021. The Law has strengthened the significance of a risk-oriented model for control and stressed the necessity to assess surveillance efficiency as per criteria related to minimizing risks for protected values and to enhance digitalization and electronic communication between all the concerned parties in the sphere.

Taking into account more specific list of objects that are subject to control fixed in the Law, we suggest a procedure for determining categories of health risks caused by specific industrial objects combined with determining a risk category for an economic activity performed by an economic entity. Risk is assessed as a combination of a probability that obligatory requirements are violated and severity of outcomes that result from such violations. The procedure allows optimal planning of control and surveillance activities regarding enterprises and organizations that perform their activities on multiple industrial sites (network companies, large holdings, etc.). We also considered an approach to creating dynamic risk-oriented checklists and suggested specific ranking for sanitary-epidemiologic requirements that were included into such checklists basing on frequency and history of violations that were committed by an object under surveillance regarding legislative requirements and risks that damage to health might occur due to such violations. The paper contains a description of methodical approaches to creating a statistic risk profile for an object under control. Creating a risk profile with mathematical procedures for data processing (including neural network modeling) allows achieving more qualitative risk detection, drawing up a maximum targeted program for a control activity, and operative reacting to types of violations that have not occurred previously.

The paper describes a principle way for introducing forms and procedures for distance control into the sanitaryepidemiologic surveillance system. It is shown that efficient distance control should be based on digitalized documents required during control and surveillance activities; maximum possible use of data taken from state, municipal, and other data sources; intensified practices of remote hardware control; as well as development and scientific and methodical support provided for an intellectual information system within control and surveillance activities.

Key words: sanitary-epidemiologic surveillance, risk-oriented model, distance control, risk profile, information system.

(C) Zaitseva N.V., May I.V., Kiryanov D.A., Babina S.V., Kamaltdinov M.R., 2021

Nina V. Zaitseva - Academician of the Russian Academy of Sciences, Doctor of Medical Sciences, Professor, Scientific Director (e-mail: znv@fcrisk.ru; tel.: +7 (342) 237-25-34; ORCID: https://orcid.org/0000-0003-2356-1145).

Irina V. May - Doctor of Biological Sciences, Professor, Deputy Director responsible for research work (e-mail: may@fcrisk.ru; tel.: +7 (342) 237-25-47; ORCID: https://orcid.org/0000-0003-0976-7016).

Dmitrii A. Kiryanov - Candidate of Technical Sciences, Head of the Department of Mathematical Modeling of Systems and Processes (e-mail: kda@fcrisk.ru; tel.: +7 (342) 237-18-04; ORCID: https://orcid.org/0000-0002-5406-4961).

Svetlana V. Babina - Head of the Information and Computing Systems and Technologies Laboratory (e-mail: bsv@fcrisk.ru; tel.: +7 (342) 237-18-04; ORCID: https://orcid.org/0000-0001-9222-6805).

Marat R. Kamaltdinov - Candidate of Physical and Mathematical Sciences, Senior researcher acting as the Head of the Department for Situation Modeling and Expert and Analytical Management Techniques Laboratory (e-mail: kmr@fcrisk.ru; tel.: +7 (342) 237-18-04; ORCID: http://orcid.org/0000-0003-0969-9252). 
In 2009 the Federal Law No. 294-FZ "On protecting rights of juridical persons and private entrepreneurs when accomplishing state control (surveillance) and municipal control" came into force; at that time it brought about significant changes in the legal regulation in the sphere of state and municipal control ${ }^{1}$. For more than 10 years this law was a central document in the state regulation and determined public interactions between control and surveillance authorities and economic entities. There were numerous alterations made into the law that reflected actual needs of the society and business ${ }^{1}$ : a concept of risk-oriented control (surveillance) was fixed; risk indicators of obligatory requirements being violated were listed; there was also an alteration on organizing and accomplishing control activities without any interactions with juridical persons / private entrepreneurs, etc.

But still, economic and social processes in the country called for further development in the legal sphere of control and surveillance activities (CSA). Annually 4 or 5 new types of state control activities were introduced, new forms of control were implemented, new instruments for control were applied, etc. But the basic principle remained valid and it stated that "lowering administrative barriers for business should not occur at the expense of neglecting safety issues" $[1,2]$.

All the above mentioned resulted in issuing the Federal Law No. 248 "On state control (surveillance) and municipal control in the Russian Federation" with its provisions being aimed at creating a new system for regulation over control and surveillance activities which can fully satisfy all the present demands.
This new model for state control (surveillance) involves the following:

- strengthening the role played by the risk oriented-approach and its further development;

- putting greater emphasis in control and surveillance on stimulating economic entities to be conscientious and law-abiding in their activities and preventing risks that damage would be done to values protected by the law;

- assessing efficiency and productivity of control and surveillance activities as per achieved risk minimization regarding damage prevention; it is not allowed to assess efficiency of activities as per direct results such as a number of accomplished control inspections, detected violations, and a number of economic entities / people made accountable for these violations;

- reducing intensity of control and surveillance activities due to developing a system of prevention activities, wider implementation of independent assessments (audit, self-assessment, risk insurance, certification procedures, etc.) etc.

It should also be mentioned that this new law stipulates the necessity to rely on electronic interactions between a control and surveillance authority and an object under surveillance.

Partially, the law has fixed the trends and approaches that have already become an integral part of control and surveillance practices performed by several federal executive authorities including the Federal Service for Surveillance over Consumer Rights Protection and Human Well-being. Thus, since 2015 Rospotrebnadzor has been basing all its sanitaryhygienic control and surveillance activities on the risk-oriented model ${ }^{3}$. CSA productivity and efficiency is assessed basing on population

\footnotetext{
${ }^{1}$ On protecting rights of juridical persons and private entrepreneurs when accomplishing state control 9surveillance) and municipal control (with alterations and supplements): The Federal Law issued on December 26, 2008 No. 294-FZ. Garant. Informational and legal support. Available at: https://base.garant.ru/12164247/ (May 20, 2021).

${ }^{2}$ On state control (surveillance) and municipal control in the Russian Federation: The Federal Law issued on July 31, 2020 No. 248-FZ. Garant. Informational and legal support. Available at: https://www.garant.ru/products/ipo/prime/ doc/74349814/ (May 20, 2021).

${ }^{3}$ MR 5.1.0116-17. Risk-oriented model for control and surveillance activities in the sphere of providing sanitaryepidemiologic well-being. Ranking economic entities, types of activities, and objects under surveillance as per potential risks of damage to health for organizing scheduled control and surveillance activities: Methodical guidelines (approved by the Federal Service for Surveillance over Consumer Rights Protection and Human Well-being. On August 11, 2017). Garant. Informational and legal support. Available at: https://www.garant.ru/products/ipo/prime/doc/71681784 / (May 20, 2021).
} 
health analysis and assessments are usually performed using reliable mathematical models for relations within "violations of obligatory requirements by objects under surveillance population mortality and morbidity" system on a territory under surveillance ${ }^{4}$.

At the same time it is obvious that the riskoriented model has a lot of potential that has not been used to the full. At present risks that might be caused by effects produced by an object on protected values are assessed within sanitaryepidemiologic surveillance only for determining periodicity of scheduled inspections. Meanwhile, the risk-oriented model provides an opportunity to take risks into account both when an inspection plan is drawn up and when decisions are made as per its results together with substantiating prevention activities ${ }^{2}$.

Sanitary-epidemiologic surveillance can be made more mature ${ }^{5}$ and control and surveillance activities can be made more efficient due to, among other things, developing regulatory and methodical support and implementing innovative approaches into activities performed by Rospotrebnadzor. It is even more vital since the law fixes several types of objects under surveillance such as activities, industrial objects, and results of activities (products and services), and each such type requires testing new control and surveillance procedures and risk assessment practices.

Digitalization may be and should be a vital trend in developing CSA performed by Rospotrebnadzor regarding both specific procedures and the overall system of control and surveillance activities. Many researchers have stressed that digitalization of control and surveillance activities is truly vital and it can be seen in many domestic and international projects ${ }^{6}[3,4]$.
According to data provided by the Higher School of Economics [1, p. 89], initially the law fixed orientation at wide-scale and profound digitalization of state control and surveillance. It was assumed that in case there were no data on a certain control and surveillance activity in an information system, such an activity should not become legally significant. Moreover, it was fixed that information technologies would automate such procedures as ranking objects under surveillance into specific risk categories, creating plans of control and surveillance activities, detecting risk indicators, selecting types of control and surveillance activities relevant for a specific situation, making a list of obligatory requirements and checklists relevant for a specific economic entity etc.

The Federal Law No. 248-FZ stipulates orientation at considerable expansion of prevention activities performed by surveillance authorities; it requires analyzing substantial amounts of information that could describe variable properties of an object under surveillance and its relations with other economic entities and provide an insight into probable effects this object could produce on the environment, both static ones and taken in dynamics over time and space. Obviously, there is a demand for Big Data processing. Digitalization provides wider opportunities for applying a result-oriented managerial model. Owing to big data public management authorities get more prompt access to data on risk sources and types and achievable (or nonachievable) results [5-7].

Undoubtedly, use of big data and scienceintensive procedures for processing formalized and digitally transformed data will secure more objective assessments obtained during

${ }^{4}$ MR 5.1.0095-14. Calculation of actual economic losses and those prevented due to control and surveillance activities caused by mortality, morbidity and disability among population associated with negative effects produced by environmental factors: Methodical guidelines. KODEKS: an electronic fund for legal and reference documentation. Available at: https://docs.cntd.ru/document/1200129398 (May 22, 2021).

${ }^{5}$ The standard for maturity of managing productivity and efficiency of control and surveillance. Approved by the Meeting Report of the Project Committee on basic trends in the strategic development of the Russian Federation "The Reform of control and surveillance activities" issued on February 13, 2018 No. 1. Garant. Informational and legal support. Available at: https://base.garant.ru/71930516/ (May 15, 2021).

${ }^{6}$ PREKOP-RF. The joint project by the European Union and European Council "Protection of entrepreneurs' rights from corruption in the Russian Federation". Regulatory and surveillance authorities of the European Council member-states responsible for accomplishing inspections and control activities in economy - structure, practices, and examples: a regulatory document, 2015, $39 \mathrm{p}$. 
control procedures [8]. Besides, automation and digitalization result in a substantial reduction in required routine and the most laborconsuming procedures, both for a surveillance authority and for an object under control. The latter allows concentrating on developing and implementing preventive activities.

The state should make a demand for relevant big data and make a decision on inspections and responsibility for violations basing on them. In other words, the state relies on distance control and it is only in exceptional cases when control procedures are to be performed directly at a place where an object under surveillance performs its activities.

At present distance control and distance monitoring as a specific type of state riskoriented control are widely used in banking and financial sphere [9-11].

Over the last 10 years distance control has been performed via wide use of hardware and instrumental monitoring means and means for recording events. Instrumental control techniques including those for uninterrupted observation are widely used in traffic control [12-14], industrial and ecological safety provision $[15,16]$, forest protection $[17,18]$, communal services $[19,20]$ etc. Distance control and monitoring seem to have a lot of potential in the sphere of providing hygienic-epidemiological safety and sanitary-epidemiologic wellbeing. Photo- and video-recording can be used in assessing conformity with obligatory requirements to activities performed by educational establishments, social objects, catering, retailing, etc. Audio-recording can be applied to assess conformity with communal hygiene requirements in places where potentially "noisy" objects are located close to residential areas. Tools used to distantly measure parameters of environmental objects can be efficient for assessing ambient air quality, chemical structure of water from the first and second intake from drinking water supply systems, temperature of hot water in a distribution network etc. Tools used in distance control over environmental objects can be successfully introduced within sys- temic control over risk indicators when social and hygienic monitoring is performed etc.

Undoubtedly, Rospotrebnadzor aims to digitalize and automate its activities ${ }^{7}$. At present the Unified Information-Analytical System (UIAS) of the Service is being implemented. UIAS is aimed at automating work processes in the basic activities performed by Rospotrebnadzor bodies and institutions as well as at external electronic interactions with state authorities, economic entities, civil society and other participants in public management in the sphere of population preservation, providing population safety and consumer right protection. Electronic data are being collected promptly in real time mode; these data are necessary for performing control and surveillance functions in the sphere of providing sanitary-epidemiologic well-being of population, protecting consumer rights and consumer markets (emergency messages about communicable diseases, complaints from citizens about sanitary-epidemiologic welfare or consumer rights being violated and some others).

In order to provide interdepartmental electronic interaction, Rospotrebnadzor and the Federal Customs Service have concluded an agreement on working out technical conditions for informational interactions between these two federal services. Rospotrebnadzor is included into development of the Interdepartmental integrated automated information system that covers all federal authorities responsible for control at entry points on the state border of the Russian Federation (IIAIS).

The state information system for consumer rights protection is active and available at Rospotrebnadzor's official web-site (http: //zpp.rospotrebnadzor.ru).

There are several interdepartmental and common public information sources that are kept operational. They include "The Register of certificates on products registration (unified form used on the Customs Union territory)"; "The Register of sanitary-epidemiologic certificates issued for products that underwent sanitary-epidemiologic examination"; "The register of licenses

\footnotetext{
${ }^{7}$ On approval of the informatization plan for this year (2020) and future 2021 and 2022: The Order by Rospotrebnadzor dated March 11, 2020 No. 148. The Federal Service for Surveillance over Consumer Rights Protection and Human Well-being. Available at: https://www.rospotrebnadzor.ru/documents/details.php?ELEMENT_ID=14590 (May 22, 2021).
} 
granted for activities involving use of communicable diseases agents and licenses for activities involving use of (generating) sources of ionizing radiation) "; "The Register of notifications about specific entrepreneurial activities now being performed"; The Federal Register of potentially hazardous chemicals and biological substances and "Hazardous substances" automated distributed information retrieval system (ADIRS), etc.

But at the same time, new legal provisions and new procedures and organization types of control and surveillance activities require concrete approaches, methodical support, precise algorithms, implementation programs, efficiency assessment criteria, etc.

Our research goal was to develop certain methodical approaches to improving sanitaryepidemiologic control (surveillance) taking into account requirements fixed in new federal legislation and digital transformation of activities performed by Rospotrebnadzor.

Data and methods. When developing new approaches, we took into account already existing documents on risk-oriented surveillance that were already implemented into routine practices by Rospotrebnadzor; valid and already invalid regulatory documents and instructions; as well as materials taken from the Technical specification on UIAS design.

Results and discussion. Developing approaches to ranking both activity types and industrial objects as per risks of potential damage to health. Clause No. 16 in the Federal Law 248-FZ stipulates that objects under surveillance include the following:

- activity (inactivity) of citizens and organizations that should comply with obligatory requirements;

- results of activities performed by citizens or organizations, including products (goods), works, or services that should comply with obligatory requirements;

- buildings, constructions, or linear objects... that belong to citizens and organizations and (or) are used by them and that should comply with obligatory requirements (hereinafter called "industrial objects")".
Objects under surveillance should be assigned into a certain risk category as per potential risks of damage to protected values (as regards Rospotrebnadzor activities, these are risks of damage to health or health risks).

Prior to 248-FZ coming into force risk categories were assigned to types of economic activities performed by economic entities within sanitary-epidemiologic surveillance activities according to Clause 8.1 in the Federal Law 294-FZ and The RF Government Order No. $806^{8}$.

The task was to assign a category as per a health risk not only for a type of activity but also specific industrial objects (buildings, constructions, etc.). And here it was assumed that industrial objects were material resources where a specific activity was performed and it was inadvisable and hardly correct to consider them separately.

Potential health risk caused by a specific activity performed by a specific juridical person (JP) or a private entrepreneur (PE) at one or several industrial objects was calculated as per the following formula (1):

$$
R^{l}=\sum_{i=0}^{n} R_{i}(l)
$$

where $R^{l}$ is potential health risk caused by $l$-th activity performed by JP or PE; $R_{i}(l)$ is potential health risk occurring at $i$-th industrial object when $l$-th activity is performed there.

Potential health risk caused by $l$-th activity performed by JP or PE at a specific industrial object is calculated as per the formula (2):

$$
R_{i}(l)=p(l) \cdot u(l) \cdot M_{i},
$$

where $R_{i}(l)$ is potential health risk occurring at $i$-th industrial object due to $l$-th activity being performed there; $p(l)$ is a probability that sanitary legislation would be violated by JP or PE at a specific object when $l$-th activity is performed there. As data on frequency of violations at different objects are accumulated, $p(l)$ should be replaced with $p_{i}(l)$ or a probability that sanitary legislation would be violated at an $i$-th-type object when $l$-th activity is per-

\footnotetext{
${ }^{8}$ On applying risk-oriented approach when organizing specific state control (surveillance) activities and making alterations into certain acts issued by the RF Government: The RF Government Order issued on August 17, 2016 No. 806. Garant. Informational and legal support. Available at: https://base.garant.ru/71473944/ (May 20, 2021).
} 
formed; $u(l)$ is a parameter that characterizes damage to health due to obligatory requirements being violated. As data on severe consequences for health due to violations at different objects are accumulated, $u(l)$ may be replaced with $u_{i}(l) . M_{i}$ is a parameter showing a number of people exposed to effects produced by $i$-industrial object (exposure scale), million people.

Probability that sanitary legislation would be violated is characterized with frequency of violations detected due to control and surveillance accomplished at objects belonging to JP and PE that perform a specific activity $(p(I))$. Value of $p(l)$ is determined as $95 \%$-th percentile in distribution of regional relative frequency revealed for violations detected during one inspection at objects under surveillance performing $l$-th activity over a 3 -year period.

The parameter that characterizes damage to health caused by sanitary legislation being violated $(u(l))$ is determined basing on systemic, including expert, analysis of cause-andeffect relations between frequency of specific clauses in the sanitary legislation being violated and health disorders prevalence becoming apparent via population mortality and primary morbidity taking their severity into account.

The parameter that shows relative frequency of violations detected during one inspection at an $i$-th object under surveillance that performs $l$-th activity is determined as per the following formula:

$$
p_{i}^{l}=\frac{m_{i}^{l}}{n_{i}^{l}}
$$

where $p_{i}^{l}$ is a parameter that shows relative frequency of violations detected during one inspection at an $i$-th object under surveillance that performs $l$-th activity and is determined taking into account data collected in all regions in the RF; $m_{i}^{l}$ shows how many violations of sanitary legislation were detected during one year at $i$-th objects under surveillance that performed $l$-th activity, units; $n_{i}^{l}$ is a total number of inspections during one year at an $i$-th object that performs $l$-th activity, units.

Frequency of violations and $95 \%$-th percentile that is taken into account in ranking are to be revised not rarer than every three years.
Both industrial objects and activity types are to be ranked using the unified scale showing potential health risk:

a) higher than $10^{-3}$ means extremely high risk;

b) from higher than $10^{-4}$ to $10^{-3}$, high risk;

c) from higher than $10^{-5}$ to $10^{-4}$, considerable risk;

d) from higher than $10^{-6}$ to $10^{-5}$, average risk;

e) from higher than $10^{-7}$ to $10^{-6}$, moderate risk;

f) lower than $1 \cdot 10^{-7}$, low risk.

Risk category is given to both an activity and to each specific industrial object. Periodicity of control is determined basing on a risk category (extremely high risk means scheduled inspections are accomplished annually; high risk, every two years; etc.).

This unified ranking that covers both activity type and industrial objects provides quite a flexible mechanism for control over JP / PE that perform their activities at multiple industrial sites and/or industrial objects (retail networks, catering networks, and networks that render services to population; large industrial holdings, etc). An overall high risk category as per an activity (see Formula 1) gives an opportunity to a surveillance authority to accomplish control over an object that, as a rule, exerts its influence on a considerable number of people (those who consume products or services, workers employed at it, or people who live in a zone exposed to it); consequently, negative outcomes caused by sanitary requirements being violated by this object are likely to be wide-scale. And lower risks detected for specific industrial objects give surveillance authorities more freedom in planning annual scheduled inspections (an example is given in Table 1).

When this or that industrial object is included into a plane of scheduled inspections, additional criteria can be taken into account; for example, environmental quality on a territory where the object is located, population density, overall sanitary-epidemiologic situation, etc. And if inspections are based on analyzing more extensive data, it can provide permanent control over activities performed by a large JP / PE without violating requirements to frequency of control procedures fixed for industrial objects. 
Table 1

A draft procedure for planning inspections at an economic entity that performs its activities at multiple industrial objects belonging to different risk categories

An activity is retail trade in food products, drinks, and tobacco goods.

Overall number of industry objects (IO) is 31 .

Risk category for the activity is extremely high risk $\left(2.03 \cdot 10^{-3}\right)$.

A surveillance authority is entitled by the law to accomplish annual scheduled inspections

\begin{tabular}{|c|c|c|c|c|c|c|c|c|c|c|}
\hline \multirow[t]{2}{*}{ No. } & \multirow[t]{2}{*}{ Risk } & \multirow[t]{2}{*}{$\begin{array}{l}\text { Any grounds for } \\
\text { change of a risk } \\
\text { category }\end{array}$} & \multirow[t]{2}{*}{$\begin{array}{l}\text { Risk category de- } \\
\text { termined for an } \\
\text { industrial object }\end{array}$} & \multirow[t]{2}{*}{$\begin{array}{l}\text { Periodicity of scheduled } \\
\text { inspections according } \\
\text { to the law }\end{array}$} & \multicolumn{6}{|c|}{$\begin{array}{c}\text { Future planning } \\
\text { (in years starting from a year } \\
\text { after the year of account) }\end{array}$} \\
\hline & & & & & 1 & 2 & 3 & 4 & 5 & 6 \\
\hline 1 & $9.6 \cdot 10^{-4}$ & no & high & Every two years & 1 & & 1 & & 1 & \\
\hline 2 & $8.7 \cdot 10^{-5}$ & no & considerable & Every three years & 1 & & & 1 & & \\
\hline 3 & $8.6 \cdot 10^{-5}$ & no & considerable & Every three years & & 1 & & & 1 & \\
\hline 4 & $7.3 \cdot 10^{-5}$ & no & considerable & Every three years & 1 & & & 1 & & \\
\hline 5 & $6.7 \cdot 10^{-5}$ & no & considerable & Every three years & & 1 & & & 1 & \\
\hline 6 & $6.6 \cdot 10^{-5}$ & no & considerable & Every three years & 1 & & & 1 & & \\
\hline 7 & $8.5 \cdot 10^{-6}$ & no & average & Not more than every 4 years & 1 & & & & 1 & \\
\hline 8 & $6.7 \cdot 10^{-6}$ & no & average & Not more than every 4 years & & 1 & & & & 1 \\
\hline$\ldots$ & & & $\ldots$ & & & & & & & \\
\hline 12 & $5.4 \cdot 10^{-6}$ & yes & considerable & Every three years & & & 1 & & & 1 \\
\hline 13 & $4.4 \cdot 10^{-6}$ & no & average & Not more than every 4 years & & 1 & & & & 1 \\
\hline 14 & $4.3 \cdot 10^{-6}$ & no & average & Not more than every 4 years & 1 & & & & 1 & \\
\hline 15 & $5.1 \cdot 10^{-7}$ & yes & considerable & Not more than every 4 years & & 1 & & & & 1 \\
\hline 16 & $5.1 \cdot 10^{-7}$ & no & average & Not more than every 6 years & 1 & & & & & \\
\hline 17 & $5.0 \cdot 10^{-7}$ & no & average & Not more than every 6 years & & & 1 & & & \\
\hline 18 & $4.9 \cdot 10^{-7}$ & no & moderate & Not more than every 6 years & & & 1 & & & \\
\hline$\ldots$ & & & & & & & & & & \\
\hline 30 & $6.4 \cdot 10^{-7}$ & no & moderate & Not more than every 6 years & & & & 1 & & \\
\hline 31 & $2.0 \cdot 10^{-7}$ & no & moderate & Not more than every 6 years & & & & & & 1 \\
\hline
\end{tabular}

Methodical approaches to creating dynamic checklists. Periodicity of scheduled control procedures that is determined with risk categories taken into account is a most essential element in risk-oriented control. But at the same time, it is only one component in the model. It is often the case that a rather wide range of obligatory requirements is fixed for a specific activity, industrial object, a product, or a service. The risk-oriented model implies that primarily surveillance authorities are to control those requirements violation of which creates the greatest risks for protected values.

The task can be solved via creating and implementing dynamic risk-oriented checklists. Obligatory requirements that are included into checklists are ranked taking into account priority of requirements determined as per risk criteria.

$I$ value is a product obtained via multiplying functions of a probability that a requirement would be violated and severity of consequences this violation would cause; this value is a criterion for determining priority of requirements (4):

$$
I=f\left(p_{k}\right) \cdot f(g),
$$

where $f\left(p_{k}\right)$ is a function of a probability that requirements would be violated by an object under surveillance at $k$-th level: at an object itself $(k=1)$, municipal $(k=2)$, regional $(k=3)$, and federal level $(k=4) . f(g)$ is a function of consequences severity ${ }^{10}$.

\footnotetext{
${ }^{9}$ Grounds for changing a risk category are fixed in the Order on types of control.

${ }^{10}$ According to the Methodical guidelines MR 5.1.0116-17.
} 
A variant for the function (4) to be used is use of weighted averaging:

$$
\begin{gathered}
f\left(p_{k}\right)= \\
=\frac{a_{1} \cdot f\left(p_{1}\right)+a_{2} \cdot f\left(p_{2}\right)+a_{3} \cdot f\left(p_{3}\right)+a_{4} \cdot f\left(p_{4}\right)}{a_{1}+a_{2}+a_{3}+a_{4}} .
\end{gathered}
$$

In case there are no representative statistic data on a probability that requirements would be violated at any level, then $a_{k}$ is considered to be equal to zero. Weight coefficients in the function are set for different $k$ levels by experts; it is advisable to assume that $a_{1}>a_{2}>a_{3}>a_{4}$.

Therefore, this formula takes into account peculiarities related to violations of obligatory requirements by objects under surveillance not only in the country in general but also in a specific region or a city / town / settlement.

Checklists can be created individually for each specific object under surveillance. Priority given to controlling requirements that are violated the most frequently or with the gravest consequences of their violation aims at making economic entities always remember that this requirement will necessarily be checked. On one hand, it is a motive for JP / $\mathrm{PE}$ to perform proactive preventive activities (and it is exactly what should be achieved via state control); on the other hand, it provides a surveillance authority with firm assurance that the main risks are given special attention.

Making checklists in formats that can be "read" by machine and having automated procedures for analyzing results obtained via filling in these checklists give an opportunity to perform logic analysis and cross-verification of data submitted by an economic entity itself (including laboratory research data obtained via industrial control) in filled checklists and data provided by other information system. It is important to analyze whether data provided by JP / PE corresponded to data obtained from external sources.

Overall, checklists are potentially considered to be dynamic systems that can change according to changes in statistic data accumulated due to inspections and analysis of their results. The latter makes them even more effective and productive for protecting citizens' life and health (regarding consumers, workers, etc.)

Methodical approaches to creating a statistic risk profile of an object under surveil-

lance. When objects under surveillance are ranked as per results obtained via generalizing the whole set of control and surveillance activities, this ranking in its essence is based on determining specific types of objects under surveillance. But at the same time each JP / PE has its peculiarities, specific internal organization, and specific quality of the environment on a territory where it performs its activities (quality of ambient air, water objects, soils; population density on nearby territories, etc.). Given that, any additional data on an object allow more precise assessment of it bearing in mind potential risks that can be caused by its activities. In this situation it seems advisable to create a "statistic risk profile of an object under surveillance". Risk profile here is seen as a multidimensional statistic model of an object under surveillance; it is a set of frequency-probabilistic properties of this object that show probable (possible) violations of sanitary legislation as well as their consequences for health and other values protected by law.

Statistic risk profiles are created using the whole set of accumulated data over the longest available period including data taken from external sources (so called information traces left by an object under surveillance). Their creation requires algorithms that can provide an opportunity to process results obtained via control and surveillance activities by machine and procedures for applying artificial intellect based on machine training of artificial neural networks. A neural network model analyzes all detected violations on typical objects basing on data that are input in real time mode; it determines risk indicators, selects significant violations of obligatory requirements and adjusts statistic risk profiles of all registered objects under surveillance. While iterative determination of significant risk indicators flows uninterruptedly, the system automatically determines a set of rules for risk assessment as per a set of typedetermining properties (an activity, a type of 
an industrial object, a territory where this object is located, etc.). A risk profile for a specific object can be adjusted taking into account historical results obtained due to accomplished inspections.

Analyzing statistic profiles of objects under surveillance allows finding solutions to tasks that are generally aimed at optimizing control and surveillance activities:

- revealing non-typical objects via searching for statistical anomalies in multidimensional space of objects' properties. Such objects can potentially be the most "risky" and require special attention from a control and surveillance authority;

- determining correlations and regressions between various digital parameters that allow assessing whether obligatory sanitary requirements are met or not;

- detecting negative influence exerted by violations of sanitary legislation on population health basing on cross-correlation analysis;

- assessing risk levels of the environment around objects and subjects due to automated building up and analyzing graphs that show their interrelations;

- structuring checklists and making them more targeted;

- organizing selective control procedures due to searching for statistically significant trends and permissible ranges of risk indicators values;

- predicting and assessing risks related to an economic entity meeting (or not meeting) obligatory requirements and standards basing on time series analysis, including, for example, use of autoregressive models with moving average, exponential smoothing, and their modifications [21, 22].

Statistic risk profiles have certain advantages:

- they allow multidimensional and precise estimates due to using big data;

- there is feedback with results of control and surveillance activities;

- infringing objects are profiled in the most optimal way due to using the most advanced mathematical procedures for data processing;

- prompt reaction since the whole set of profiles is renewed automatically and simultaneously;
- there is an opportunity to prevent risks due to reacting to new violations that have not occurred before;

- new risk indicators: use of additional automatically calculated risk indicators in all the other modules in the system;

- better quality achieved in risk detection due to additional data (spotting out closely connected unities out of a common graph and analyzing dynamics of a risk spreading as per a graph; assessing risk significance and risk levels for specific nodes and relations; revealing pathways between objects and subjects);

- interpretation is simple and obvious since all the obtained data are given graphically and can be easily used in any activity aimed at risk minimization.

Risk profiles should be renewed constantly; it requires feeding data on results obtained via accomplished inspections into the risk management system. "Feedback" allows maintaining precision of risk assessments via increasing or reducing significance of a subject's initial parameters depending on inspection results. Data used for building up a risk profile for a specific object are analyzed basing on the whole set of results obtained via control and surveillance activities regardless of a surveillance procedure that was applied in this or that case.

Approaches to implementing distance control basing on digitalization and automation of control and surveillance activities. If we wish to develop control and surveillance activities given new alterations into the existing legislation, to provide dynamic ranking of objects under surveillance and to build up correct statistic risk profiles for them, to optimize checklists contents, and to plan efficient control and surveillance procedures, we need to constantly improve organization of information flows and big data processing. And this requirement is common for all public management systems, both in Russia and abroad [23-30].

There is an official document entitled "The National action plan aimed at providing recovery of employment and population incomes, economic growth, and long-term structural changes in the economy". The document envisages developing a concept of distance control / 
monitoring ${ }^{11}$ and it is well in line with striving to digitalize and automate activities performed by Rospotrebnadzor. This concept includes creating and using information technologies and technical tools aimed at making control and surveillance activities automated so that they do not require direct (contact) interaction with economic entities. It is assumed that control and surveillance activities (both scheduled and offscheduled ones) can be accomplished via distant interaction between experts from Rospotrebnadzor's bodies and institutions and those who represent economic entities. Basic surveillance procedures are automated due to using functional capabilities offered by an intellectual information system that operates relying on analytical algorithms for data processing including artificial intellect. In future the system will allow a significant increase in a share of distance control over activities performed by JP / PE as well as over quality and condition of buildings, constructions, products, and services.

A principle scheme showing how distance control procedures can be included into the overall system for automation of control and surveillance procedures performed by Rospotrebnadzor is given in Figure.

The system includes the following key elements:

- databases included into the Rospotrebnadzor's Unified information and analytical system;

- databases that belong to external sources (open access DB and DB that are open for information exchange with Rospotrebnadzor basing on bilateral agreements);

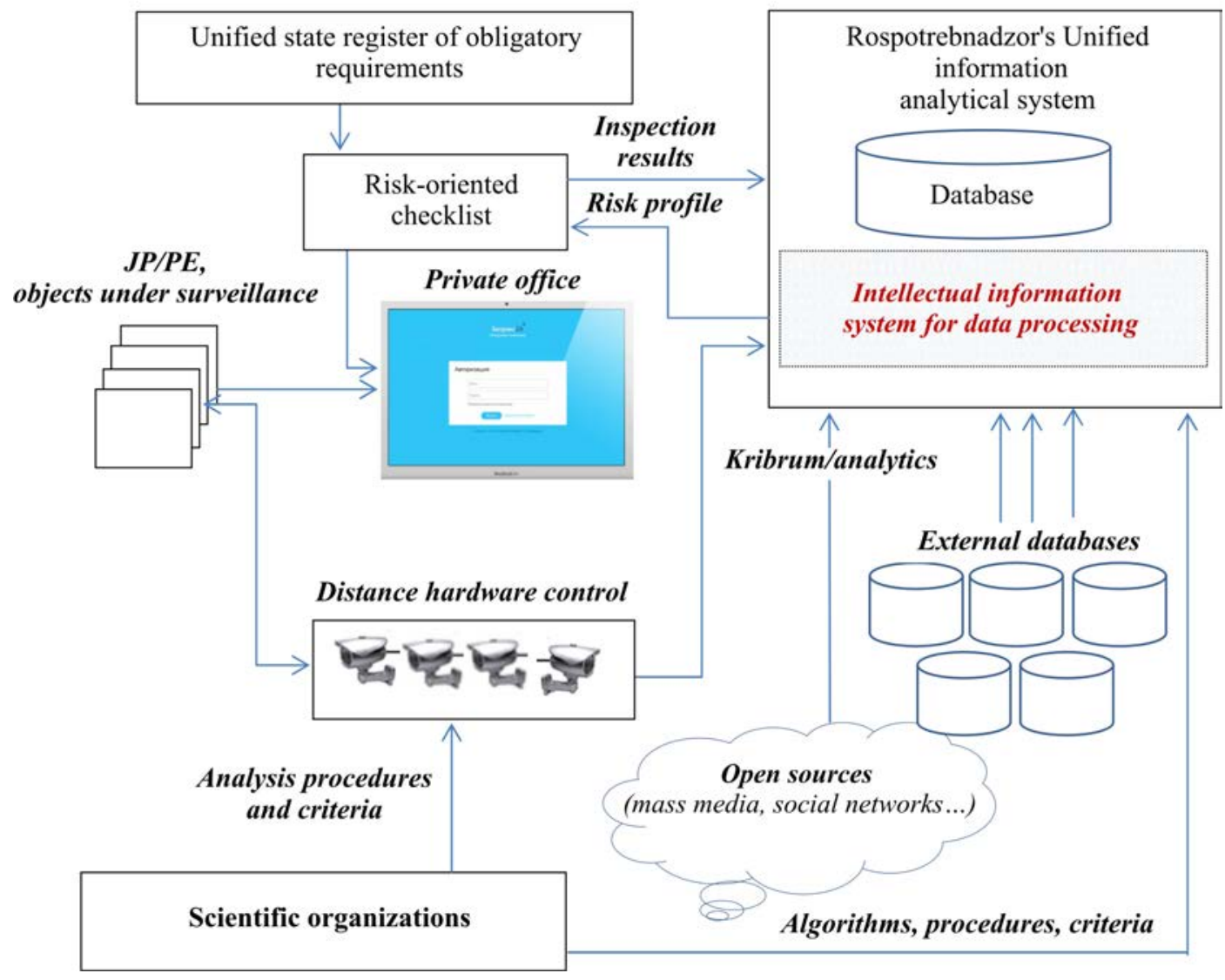

Figure. A principle scheme showing how distance control procedures can be included into the overall system for automation of control and surveillance procedures performed by Rospotrebnadzor

\footnotetext{
${ }^{11}$ The National action plan aimed at providing recovery of employment and population incomes, economic growth, and long-term structural changes in the economy (approved by the RF Government on September 23, 2020. (The meeting report No. 36, section VII) No. P13-60855 dated October 2, 2020). Informational and legal support. Available at: https:// www.garant.ru/products/ipo/prime/doc/74678576/ (May 20, 2021)..
} 
- a private office of an object under surveillance that allows communication with a surveillance authority;

- communication means;

- intellectual information system that provides science-intensive processing of all incoming data including those coming from distance hardware control.

An intellectual information system can become a powerful tool in providing information and analytical support for control and surveillance procedures including distance ones; its development and implementation requires wide-scale and comprehensive formalization of all processes, procedures, and specific actions performed by inspecting authorities and their transfer into electronic form.

It provides the following:

- unified interaction between all participants in control and surveillance activities;

- connection and possibility to exchange data with external information sources (both state-owned and private ones), optimized and automated preparation of all documentation necessary for a control procedure; data transfer, storage and further analytical processing as regards results obtained via control and surveillance activities.

This intellectual information system is a set of software-hardware and informationanalytical solutions that provide an opportunity for all participants in control and surveillance activities and other concerned parties to fulfill their responsibilities, exercise their rights, and interact electronically.

The intellectual information system, together with data provided by UIAS belonging to departmental information systems (Rospotrebnadzor's UIAS) should provide complex analysis of results obtained via control and surveillance activities as per all control and surveillance procedures. This analysis allows the following:

- revealing the most common problems related to meeting (failing to meet) safety requirements as per a specific activity, territory, economic entity, its production capacity and specific technological processes, types and volumes of manufactured products, a period of time during which production facilities have been in operation, etc. (as per any parameter that is included into a relevant profile in a surveillance register);

- dynamic adjustment of checklists taking revealed priorities into account;

- analyzing legal practices existing in different regions when the same violations are detected there;

- analyzing productivity of administrative measures taken as a response to a violation including analysis as per a specific activity, economic entity, etc. (no repeated violations, all instructions fulfilled timely etc.);

-assessing and predicting risks that obligatory requirements would not be met by economic entities performing specific activities, belonging to a specific category, located in a specific region etc.;

- detecting and analyzing a relation between violation of obligatory requirements and condition of protected values (environmental quality, occupational morbidity, morbidity and mortality among population including products and services consumers etc.) taking into account results obtained via a specific surveillance activity; combined with data on conditions of protected values (via a connection with SHM module, data obtained from other information systems);

- creating a system of targeted preventive activities aimed at preventing violation of obligatory requirements including raising awareness among economic entities about risks that obligatory requirements would be violated occurring at similar objects and best available practices for minimizing such risks.

The most important task here is to analyze the greatest available information volume and, basing on it, to reveal logic in sanitary requirements violations; to parameterize relations between violations of sanitary requirements and other parameters of activities performed by economic entities or conditions of buildings and constructions; to reveal a wide range of risk indicators showing that sanitary requirements might be violated. The latter allows taking proactive decisions in case there are data in any external system indicating that criteria parameters of risk indicators were exceeded.

In future analysis might also include data taken from mass media and social networks. There is experience in using such data, includ- 
ing consumer rights protection; and kribrum techniques (a service that allows examining and monitoring interests, opinions, and demands of networks users) are widely used in marketing, business organization, public opinion studies and studies on people's confidence in public authorities [31].

Therefore, risk-oriented model of control and surveillance activities is combined with risk management elements (hedging). The latter fully corresponds to goals and tasks of sanitary-epidemiologic service since its primary mission is to minimize and prevent risks, dangers, and threats for life and health of country citizens.

Successful functioning of the system to a great extent depends on scientific and methodical support provided for solving each set task.

Conclusions. Taking into account changes in legislative basis of control and surveillance activities and digitalization of functions performed by public authorities in the Russian Federation, we suggest several methodical approaches aimed at developing the existing base of risk-oriented sanitary-epidemiologic surveillance. These approaches provide the following:

- ranking specific industrial objects (as objects under surveillance) as per risks that might cause damage;

- developing statistic risk profiles for objects under surveillance;

- creating dynamic risk-oriented checklists;
- implementing distance control basing on digitalization and automation of control and surveillance activities.

It appears that recommended methodical approaches supplemented with other procedures (non-numeric data statistics, fuzzy theory; neural networks, genetic algorithms, etc.) can provide new prospects in sanitary-epidemiologic control (surveillance) organization and make for the following:

- correctly determined priority risk sources and factors and the strictest control over them together with minimized control over objects and factors with low or insignificant risks of any damage to protected values;

- maximum precise prediction on changes in a situation and iterative development of control and surveillance activities that involves making them more targeted taking into account a constantly renewed data base on results obtained via control activities;

- gradual transformation of scheduled control and monitoring over objects under surveillance with wide use of distance hardware monitoring and science-intensive analysis of all the available data on an object under surveillance and on potential recipients who might be exposed to its influence.

Funding. The research was not granted any financial support.

Conflict of interests. The authors declare there is no any conflict of interests.

\section{References}

1. Plaksin S.M., Abuzyarova I.A., Kashanin A.V., Knutov A.V., Polesskii E.A., Sakaev A.Sh., Semenov S.V., Sinyatullina L.Kh. [et al.]. Rossiiskii soyuz promyshlennikov i predprinimatelei; Nats. issled. un-t «Vysshaya shkola ekonomiki». Kontrol'no-nadzornaya i razreshitel'naya deyatel'nost' v Rossiiskoi Federatsii. Analiticheskii doklad - 2019 [Control and surveillance and licensing activity in the Russian Federation. The analytical report - 2019]. Moscow, NIUVShE Publ., 2020, 138 p. (in Russian).

2. Bozhukova E.M., Chechulina A.A. Reform of the control (supervisory) activities. Voprosy rossiiskogo i mezhdunarodnogo prava, 2021, vol. 11, no. 3-1, pp. 101-110 (in Russian).

3. Sidorenko E.L., Bartsits I.N. The efficiency of digital public administration assessing: theoretical and applied aspects. Voprosy gosudarstvennogo i munitsipal'nogo upravleniya, 2019, no. 2, pp. 93-114 (in Russian).

4. Dobrolyubova E.I., Yuzhakov V.N., Efremov A.A., Klochkova E.N., Talapina E.V., Startsev Ya.Yu. Tsifrovoe budushchee gosudarstvennogo upravleniya po rezul'tatam [Digital future of result-oriented public administration]. Moscow, Delo; RANKhiGS Publ., 2019, 114 p. (in Russian).

5. Dzhumaeva Ya.M.Kh., Bachaev A.A., Gorgiev R.T. Main features of the results-based public administration model. FGU Science, 2021, vol. 21, no. 1, pp. 47-50 (in Russian). 
6. Wahyunengseh R.D., Hastjarjo S. Big Data Analysis of Policies on Disaster Communication: Mapping the issues of communication and public responses in the government social media. IOP Conference Series: Earth and Environmental Science, 2021, vol. 717, no. 1, pp. 012004. DOI: 10.1088/17551315/717/1/012004

7. Awaysheh F.M., Alazab M., Gupta M., Pena T.F., Cabaleiro J.C. Next-generation big data federation access control: A reference model. Future Generation Computer Systems, 2020, no. 108, pp. 726-741.

8. Dyumina A.A. Forms and methods of the state control (supervision) of transport security. Biznes. Obrazovanie. Pravo, 2019, vol. 47, no. 2, pp. 309-317 (in Russian).

9. Tsakaev A.Kh. Proportional regulation and risk-oriented supervision of the financial market: theory and practice. Finansovyi menedzhment, 2020, no. 3, pp. 100-109 (in Russian).

10. Boyarkina O.V. The use of information systems in the implementation of state financial (budget) control. Colloquium-journal, 2019, vol. 49, no. 25-8, pp. 183-187 (in Russian).

11. Danilova A.D. Distantsionnyi kontrol' s ispol'zovaniem risk-orientirovannoi sistemy v kontrol'no-nadzornoi deyatel'nosti nalogovoi sluzhby [Distance control that involves using a risk-oriented system in control and surveillance activities performed by a tax service]. Shag v budushchee: iskusstvennyi intellect $i$ tsifrovaya ekonomika. Revolyutsiya $v$ upravlenii: novaya tsifrovaya ekonomika ili novyi mir mashin: materialy II Mezhdunarodnogo nauchnogo foruma, 2018, pp. 85-90 (in Russian).

12. Bezdenezhnykh S.N., Ziyatdinov A.M., Gumerov A.V. Rolling stock information \& measuring systems: remote monitoring and train condition control. Vestnik NTsBZhD, 2019, vol. 42, no. 4, pp. 172-176 (in Russian).

13. Knyshev I.P., Gusarova E.V., Tulemisov T.T. Technical vision system on railway transport. Avtomatika, svyaz', informatika, 2019, no. 10, pp. 15-17 (in Russian).

14. Savin G.V. Intelligent transport system: optimizing streaming processes in the city - outline of future changes. Russian Economic Bulletin, 2020, vol. 3, no. 6, pp. 101-108 (in Russian).

15. Biryukov A.N., Sitkina Yu.G. Distantsionnyi kontrol' sostoyaniya otkosnykh sooruzhenii [Distance control over a state of slope constructions]. Gornyi informatsionno-analiticheskii byulleten' (nauchno-tekhnicheskii zhurnal), 2010, no. S2, pp. 143-145 (in Russian).

16. Dem'yanov V.V., Galanina T.V., Lyubimova K.V. Distantsionnyi ekologicheskii monitoring geologicheskoi sredy pri tekhnogennykh vozdeistviyakh [Distance ecological monitoring over geological environment under technogenic impacts]. Gornyi informatsionno-analiticheskii byulleten' (nauchno-tekhnicheskii zhurnal), 2011, no. 7, pp. 175-177 (in Russian).

17. Abushenko N.A., Bartalev S.A., Belyaev A.I., Ershov D.V., Zakharov M.Y., Loupian E.A., Korovin G.N., Koshelev V.V. [et al.]. Near Real-time Satellite Monitoring of Russia for Forest Fire Protection. Mapping Science and Remote Sensing, 1999, vol. 36, no. 1, pp. 54-61. DOI: 10.1080/07493878.1999.10642107

18. Vasil'eva M.A. Remote monitoring in investigation of illegal cabins of forest plantings. Territoriya novykh vozmozhnostei. Vestnik Vladivostokskogo gosudarstvennogo universiteta ekonomiki $i$ servisa, 2014, vol. 26, no. 3, pp. 142-145 (in Russian).

19. Yuan F., Bauer M.E. Comparison of impervious surface area and normalized difference vegetation index as indicators of surface urban heat island effects in LANDSAT imagery. Remote sensing of Environment, 2007, vol. 106, pp. 375-386. DOI: 10.1016/j.rse.2006.09.003

20. Paris suburb pioneers 'noise radar' to fine roaring motorcycles. Reuters. Available at: https://www.reuters.com/article/us-france-noise-motorcycles/paris-suburb-pioneers-noise-radar-tofine-roaring-motorcycles-idUSKCN1VK1AA (20.05.2021).

21. Box G.E.P., Jenkins G.M., Reinsel G.C., Ljung G.M. Time series analysis: Forecasting and control. New Jersey, 2015, 712 p.

22. Hyndman R.J., Athanasopoulos G. Forecasting: principles and practice. Melbourne, 2018, $380 \mathrm{p}$.

23. Konyukova O.L., Letunov S.A. Role of digitalization in public administration. Global \& regionnal research, 2019, vol. 1, no. 1, pp. 74-79 (in Russian).

24. Kas'yanov S.V. Digital transformation as the new driver improve the efficiency in the system of state and municipal management. Regional'nye problemy preobrazovaniya ekonomiki, 2019, vol. 107, no. 9, pp. 5-12. 
25. Dvinskikh D.Yu., Dmitrieva N.E., Zhulin A.B., Plaksin S.M., Pliss M.A., Sinyatullina L.Kh., Styrin E.M., Faiziev S.A. Tsifrovaya transformatsiya gosudarstvennogo upravleniya: mify i real'nost': doklad k XX Aprel'skoi mezhdunarodnoi nauchnoi konferentsii po problemam razvitiya ekonomiki i obshchestva: sbornik nauchnykh statei [Digital transformation of public administration: myths and reality. The report for the $20^{\text {th }}$ April international scientific conference on public and society development: a collection of research papers]. Moscow, Izd. dom Vysshei shkoly ekonomiki Publ., 2019, pp. 19-21 (in Russian).

26. Smotritskaya I.I. State administration in conditions of development digital economy: strategic challenges and risks. Etap: Ekonomicheskaya teoriya, analiz, praktika, 2018, no. 4, pp. 60-72 (in Russian).

27. Digital strategy 2025. Federal Ministry for Economic Affairs and Energy. Available at: https://www.de.digital/DIGITAL/Redaktion/EN/Publikation/digital-strategy-2025.html (20.05.2021).

28. Blanc F., Franco-Temple E. Introducing a risk-based approach to regulate businesses: how to build a risk matrix to classify enterprises or activities. Nuts \& bolts. Washington, DC, World Bank Group Publ., 2013, 8 p.

29. BRDO Proposals for Developing a Common Approach to Risk Assessment. BRDO: professional development and culture changes resources, 2012, $16 \mathrm{p}$.

30. Faure M. Environmental Enforcement Networks. Concepts, Implementation and Effectiveness. Cheltenham/Northampton, Edward Elgar Publishing Publ., 2015, 576 p.

31. Zimova N.S., Fomin E.V., Smagina A.A. Social networks as a new channel of interaction between government and society. Nauchnyi rezul'tat. Sotsiologiya i upravlenie, 2020, vol. 6, no. 2, pp. 159-171 (in Russian).

Zaitseva N.V., May I.V., Kiryanov D.A., Babina S.V., Kamaltdinov M.R. Sanitary-epidemiological surveillance: a new stage in development stimulated by digitalization and changes in legislation. Health Risk Analysis, 2021, no. 2, pp. 4-17. DOI: 10.21668/health.risk/2021.2.01.eng

Received: 09.04.2021

Accepted: 28.06.2021

Published: 30.09 .2021 